\title{
Pesticide evaluation in water, sediment and in oyster shells (Crassostrea rhizophorae) in the Manzanillo- Niquero coastal area, Cuba
}

\author{
Mayelin Alvarez Vázquez ${ }^{1}$, Gustavo Arencibia-Carballo ${ }^{1}$ Abel Betanzos-Vega ${ }^{1}$, \\ Mario Formoso García ${ }^{1}, \&$ Arturo Tripp-Quezada ${ }^{2}$
}

\author{
${ }^{1}$ Centro de Investigaciones Pesqueras, Calle 246 \# 503 e/ 5ta y Mar, Santa Fé, Playa, La Habana, Cuba. \\ ${ }^{2}$ Instituto Politécnico Nacional, Unidad Centro Interdisciplinario de Ciencias Marinas, Col. Playa Pal o Santa Rita, Ap. 592, La \\ Paz, México
}

\begin{abstract}
Occasionally pesticides have been used excessively for the pest control in agriculture, and many of these compounds become toxic for living organisms, including man. Adjacent lands to Guacanayabo gulf, Cuba, show an important use in agriculture, mainly in rice due to the contribution of fluvial waters from several hydrographical basins. The coastal area from Manzanillo to Niquero, Granma province, is the habitat of commercial shrimps, oysters and fish. The objective of the study was to determine in that region the presence of chemical residues from pesticides in the waters, sediments and shells of the mangrove oyster Crassostrea rhizophorae, Guilding (1828), as indicators of contamination. Samplings were carried out in maximum rainfall months. Besides samples for pesticide determination by gas chromatography, hydrology was studied, and there were carried out surveys ( 85 farmers) to know about pesticide types, dose and application frequency per crop, for conceptual analysis of the study objective. Results indicate a non-affectation by chemical residues of pesticides in any of the evaluated matrixes; and satisfactory quality of the waters for fishing use according to the used hydrological indicators. Ignorance exists on the farmer part on the application and dose of these chemical products, and recommendations are offered on pesticide use to prevent future impacts on the ecosystems.
\end{abstract}

Keywords-Crassostrea rhizophorae, Guacanayabo gulf, pesticides, marine sediments, Cuba.

\section{INTRODUCTION}

In the southern area of the Guacanayabo gulf, it is carried out the commercial capture of Penaeus sp. shrimps, fish and crustaceans as the common lobster of the Caribbean Panulirus argus (Latreille, 1804), and the mangrove oyster (C. rhizophorae).
In Cuba, the capture of these resources has diminished in the last 20 years, due to different natural factors and of human origin, such as the damming of rivers and its consequent reduction in the contribution of nutritious inorganic to the coastal area (Baisre and Arboleya, 2006). Contamination has also been pointed out by heavy metals and chemical pesticides coming from agriculture (Arencibia-Carballo et al., 2014). Due to the fishing environmental and biological importance of the ManzanilloNiquero coastal region, the irrational use of pesticides constitutes a serious problem, due to the adverse effects that it causes in the health of the aquatic and marine organisms, as well as in coastal ecosystems and the environment (Arencibia, 2005).

Although one knows that in the last years it has happened a decrease in Cuba of the inorganic sources of contamination (Montalvo et al., 2010) and less toxic pesticides to the environment and man are used, as the buprofezin insecticide, used for the control of insectpests in rice and potato (Orta-Arrazcaeta, 2002), it is necessary to diminish risks associated to indiscriminate use of the same ones (Concepción-Villanueva et al., 2016).

The study of pesticide residues facilitates the evaluation of the level of contamination (Zhang et al., 2012). The Fishery Research Center (CIP) of Cuba carries out an environmental monitoring in a periodic way, in waters, sediments and organisms of fishing interest, where pesticide determination is a complementary analysis. Being the objective of the present paper the determination of residues of chemical pesticides in water and superficial marine sediment, as well as in shells of mangrove oyster (Crassostrea rhizophorae), of the Manzanillo-Niquero coastal area, in the Guacanayabo gulf. 


\section{MATERIALS AND METHODS}

The study area is located in the southeastern region of Cuba, Granma province, and it covered the coastal area, from $20^{\circ} 21.204^{\prime} \mathrm{N}$ and $077^{\circ} 08.156^{\prime} \mathrm{W}$ (Manzanillo city) up to

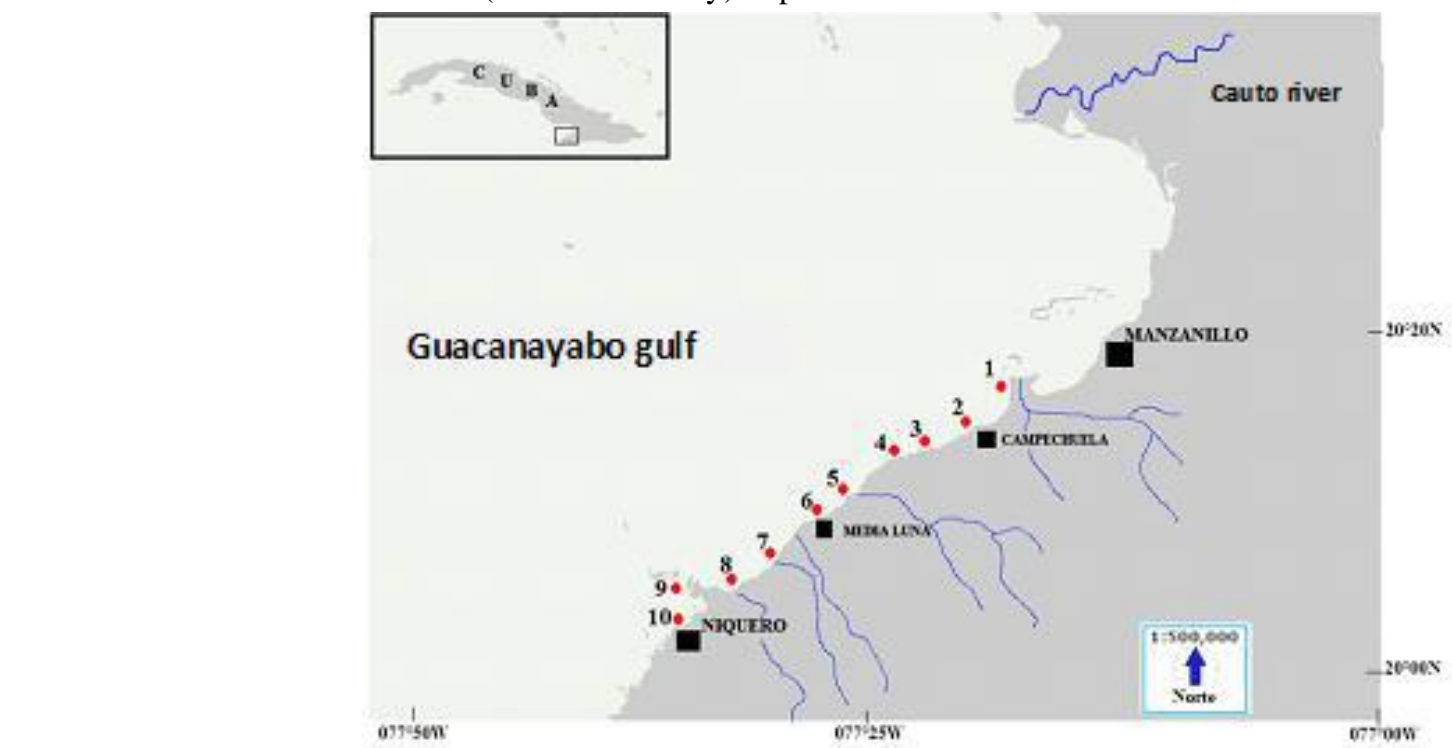

Fig.1: Sampling network, main populations and hydrographical basins in the study area. $20^{\circ} 03.276^{\prime} \mathrm{N}, 077^{\circ} 36.266^{\prime} \mathrm{W}$ (Niquero municipality), it has a total surface of $8969 \mathrm{~km}^{2}$ and a current population of 47 475 inhabitants, (Fig. 1). work included 10 coastal seasons (Fig. 1) The sampling network included 10 coastal seasons (Fig. 1)
that were sampled in May and June, 2016, months of high temperature and rainfalls, since high temperatures increase the incidence of pests and the use of chemical pesticides can increase, and significant rainfalls induce a bigger terrigenous runoff with a bigger probability of contamination of coastal marine ecosystems.

For pesticide residues there were taken sediment samples in all seasons, water samples in four seasons and oyster shells in the region of Campechuela, forming a sample made up of 10 shell kg.

Water samples were collected with a Van Dorn bottle at 30 cm depth and stored in wide mouth amber glass bottles while sediment samples were collected with a dredger and they were stored in black nylon bags, being conserved frozen until their transfer to the destination laboratories.

Oyster shell samples went to the Research Center for the Mining and Metallurgical Industry (CIPIMM) to be grinded and to homogenize in a ball mill, next, they were sifted to $0.1 \mathrm{~mm}$ and they were sent joined to the samples of the different matrixes to the Chemistry laboratory of the National Institute for Vegetable Health Research (INISAV) for the analysis of pesticide residues in a gas chromatograph, M- DANI brand, whose detection limit for quantification is $0.2 \mu \mathrm{g} / \mathrm{L}$ and an uncertainty based on the standard deviation of0.4 (Ricardo-Mariño, 2009).

In each season, there were carried out in situ recordings of water temperature $\left({ }^{\circ} \mathrm{C}\right), \mathrm{pH}$, salinity (ups), oxygen saturation $(\%)$, concentration of dissolved oxygen $\left(\mathrm{mg} \mathrm{L}^{-1}\right)$ and total dissolved solids $(\mathrm{mg} / \mathrm{L})$, at $0.50 \mathrm{~m} \mathrm{depth}$, with a HANNA HI 9828 multi-parametric probe with an error (precision) of \pm 0.1 units. Data averages are shown with their standard deviation ( \pm DS). In parallel it was carried out a survey to 85 farmers that inhabit near towns to the coastal area, to obtain information about the pesticide type used, dose and application frequency by crop types, for conceptual analys is of the outlined study object (I annex 1).

\section{RESULTS AND DISCUSSION}

The results of hydrological sampling are shown in Table 1. They indicate that the evaluated parameters didn't show indicative values of contamination, with concentrations in salinity $(<34.7)$, of oxygen over $4 \mathrm{mg} / \mathrm{L}$ and dis solved solids $(<100 \mathrm{mg} / \mathrm{L})$, so it is considered of Good and Fair quality according to NC-25 the Cuban standard for fishing use (1999). 
Table.1: Summary of standard hydrological parameters according to sampling seasons.

\begin{tabular}{cccccccc}
\hline No. & Season & Temp. ${ }^{\circ} \mathrm{C}$ & $\begin{array}{c}\text { Salinity } \\
(\mathrm{UPS})\end{array}$ & $\mathrm{pH}$ & $\begin{array}{c}\text { Dissolved } \\
\text { Oxygen (mg/L) }\end{array}$ & $\begin{array}{c}\text { Oxygen } \\
\text { Saturation } \\
\%\end{array}$ & $\begin{array}{c}\text { SD } \\
(\mathrm{mg} / \mathrm{L})\end{array}$ \\
\hline 1 & Punta Gua & 28.13 & 34.20 & 7.82 & 4.75 & 71.4 & 44.08 \\
2 & Campechuela & 28.53 & 34.57 & 8.33 & 4.41 & 67.8 & 54.32 \\
3 & CeibaHueca & 28.84 & 34.69 & 8.13 & 4.25 & 65.1 & 55.37 \\
4 & San Ramón & 28.73 & 34.63 & 8.08 & 4.86 & 77.4 & 51.31 \\
5 & Media Luna & 28.67 & 34.33 & 8.11 & 5.19 & 80.2 & 53.11 \\
6 & Punta Monacal & 28.96 & 34.34 & 8.29 & 5.54 & 85.1 & - \\
7 & Tanariver & 28.88 & 33.58 & 8.19 & 5.34 & 82.3 & - \\
8 & Sevilla river & 29.03 & 33.90 & 8.39 & 4.92 & 76.3 & - \\
9 & PasaBalandra & 28.56 & 34.02 & 8.38 & 5.16 & 79.9 & 53.82 \\
10 & Niquero & 28.86 & 29.58 & 7.98 & 5.42 & 80.5 & 63.55 \\
\hline Mean & The whole region & 28.71 & 33.78 & 8.17 & 4.98 & 76.6 & 52.73 \\
SD $( \pm)$ & The whole region & 0.26 & 1.52 & 0.18 & 0.43 & 6.50 & 5.30 \\
Max. & The whole region & 29.03 & 34.69 & 8.39 & 5.54 & 85.1 & 63.55 \\
Min. & The whole region & 28.13 & 29.58 & 7.82 & 4.25 & 65.1 & 44.08 \\
\hline
\end{tabular}

The region showed a water temperature of $28.71 \pm 0.26{ }^{\circ} \mathrm{C}$, the mean salinity of $33.78 \pm 1.52$ ups, relatively low although characteristic of the period, and very similar to the mean (33.46 \pm 1.12 ups) obtained for the region by Betanzos et al., (2012) for the rainy period 2008 and 2009; although annual values means of this variable are located between 36.5 and 37 ups for that region (Fernández-Vila et al., 2010).

The $\mathrm{pH}$ showed values characteristic of marine waters, and the average concentration and saturation of oxygen are acceptable, keeping in mind that the region shows a high degradation of organic matter, and bigger oxygen consumption than production of the same one (Montalvo and Perigó, 1999); The results of pesticide residues demonstrate that contamination doesn't exist in the coastal area below $0.2 \mu \mathrm{g} / \mathrm{L}$, which could be a consequence that in the last years they have been applied rationally, or due to low concentrations, and when being highly biodegradable compounds in the marine ecosystem, added to the high temperatures of the region, they're not detectable with the techniques being used.

Pesticide analyses didn't detect chemical residues in water, sediment, or accumulations in the oyster shells (Table 2), (quotation).

The results of the surveys carried out for the same period of study in the population of the coastal area are shown.

Table.2: Result of the 85 surveys carried out.

\begin{tabular}{|c|c|c|c|}
\hline Total of surveys & No. (\%) & & \\
\hline Reject & $34(40 \%)$ & & \\
\hline Accepted & $51(60 \%)$ & & \\
\hline Men & $43(84.3 \%)$ & & \\
\hline Women & $8(15.6 \%)$ & & \\
\hline Response & Yes & No & I don't know \\
\hline Question 1 & $15(29.41 \%)$ & $25(49.01 \%)$ & \begin{tabular}{|c|}
$11(21.56 \%)$ \\
\end{tabular} \\
\hline Question 2 & $10(19.60 \%)$ & $41(80.39 \%)$ & \\
\hline Question 3 & $5(9.80 \%)$ & $46(90.19 \%)$ & \\
\hline Question 4 & \multicolumn{2}{|c|}{ Only 9 comments } & \\
\hline
\end{tabular}

Statistically one can say that it exists $99 \%$ that the substance is not present in the matrixes, with $1 \%$ probability that the substance detected in the MDL be considered present when the real concentration is 0 (Type I Error).
These results are more representative in sediment than in water, since chemical residues are retained in the surface of the same one during one year, and in more depth during several years, according to the sedimentation rate. However, 
a bigger representativeness in the sampling of superficial water requires several samplings at different times and with more frequency, because when there are marine currents, it is constantly flowing and chemical residues are not retained because they're beingdrawn by the same ones. It also could be sampled the sediment of the intertidal area as the high tide and low tide processes can contribute to their deposition in the coastal coast area.

Absence of chemical pesticides in the study area can be used as baseline to evaluate future events that can involve these compounds, which would allow a precise analysis of their persistence, bioaccumulation and toxic action in the ecosystems or marine organisms, because if there exists contamination, it can cause an unbalance in the vital cycle of some resident species, altering their reproduction (Piset al., 2014).

Concepción-Villanueva et al. (2010) reported that during the years 2003 - 2008, in the Cauto basin, to the northeast of the Guacanayabo gulf, there have been endosulfan residues in sediment and water, which is an organochlorine chemical pesticide used for the control of pests in some crops like rice, tomato, and coffee, among other. So it becomes necessary to use more precise methods of analysis, since in the adjacent agricultural region to the coastal area agricultural cultivations exist, in state and private parcels, where the use of insecticides can be a practice in pest control.

In the last years Cuba has reduced the use of chemical pesticides in50 \% (Del Puerto-Rodríguez et al., 2014). Insecticides and fungicides are being developed; less and less toxic to the human being, as well as less persistent in the environment, as the buprofezin and carbaryl insecticides (Official List of Authorized Pesticides, 2016).

Methods of integrated handling of pests and agrienvironment politics are also developed. This has allowed the significant substitution of imported chemical pesticides, decrease of the toxic load on the ground and underground waters, improvement of the conservation of functional biodiversity, among other(Vázquez-Moreno, 2006). All which could justify the results obtained in the analyzed samples of the different matrixes .

Methods of integrated handling of pests and agrienvironment politics are also developed. This has allowed the significant substitution of imported chemical pesticides, decrease of the toxic load on the ground and underground waters, improvement of the conservation of functional biodiversity, among other.

The results of applied surveys don't allow to draw conclusions, but they give a vision of the risk, although it is recognized that the type of question to formulate and the hypothesis of the problem, determine in great measure the research design that we should use (Meltzoff, 2000).

\section{CONCLUSIONS}

There were not found residues of chemical pesticides in the different evaluated matrixes, for what it is considered that the evaluated coastal area doesn't present contamination due to pesticides.

Hydrological variables showed acceptable quality and in consequence with the period of sampling, of significant rainfalls.

An ignorance of the appropriate use of pesticides exists on the part of some (put the \%) farmers

\section{RECOMMENDATIONS}

Annually maintain a pesticide monitoring in critical points of the Manzanillo-Niquero coastal area.

Carry out pesticide analysis not only in the oyster shell but also in samples of the animal meat.

\section{THANKING}

We thank the associates of the EPIGRAN Company of Granma for their collaboration, as well as the workers of the INISAV laboratory of chemistry and the colleagues of CIPIM who carried out the grinding of the samples.

\section{REFERENCES}

[1] Arencibia-Carballo, G. 2005. Contaminación e impacto ambiental en la bahía de Nipe, Cuba: Recomendaciones para su manejo. Tesis para obtener el grado de Doctor en Ciencias.

[2] Arencibia-Carballo, G., Sánchez, F., Seisdedo, M. 2014. Determinación de hidrocarburos aromáticos policíclicos en sedimentos superficiales de la zona costera del golfo de Guacanayabo, Cuba. Bol. Cient. 32: $17-25$.

[3] Avila, J., Núñez, L. M. G., y Obiol, T. 2004. Evaluación de variedades de arroz en la zona oriental de Cuba. Agronomía Mesoamericana, 15(1), 17-24. 8 pp.

[4] Baisre, J. A. y Arboleya, Z. 2006. Going against the flow: Effects of river damming in Cuban fisheries. Fish. Res., 81: 283-292.

[5] Betanzos, A., Garcés, Y., Delgado, G. y Pis, M. A. 2012. Variación espacio-temporal y grado de eutrofia de sustancias nutrientes en aguas de los golfos de Ana María y Guacanayabo, Cuba. Revista Marina y Costera 4: 117-130.

[6] Concepción-Villanueva, J., Arencibia-Carballo, G., Carballo, O., Sánchez, F., Capetillo-Piñar, N., 
Hernández, T., Isla-Molleda, M., Almeida, R. 2010. Estado ambiental de la zona costera Manzanillodesembocadura del río Cauto. 11pp. Disponible en:

[7] http://www.oceandocs.org.

[8] Del Puerto-Rodríguez, A. M, Suárez, S., Palacio, D. E. 2014. Efectos de los plaguicidas sobre el ambiente y la salud. Rev cubana HigEpidemiol 52(3). Ciudad de la Habana set.-dic. 2014. Versión On-line ISSN 15613003.Fernández-Vila, L.J., López-García, D. y Ramírez-Stout, O. 2010. Características termohalinas de las aguas de la plataforma cubana. Memorias del VI Taller Internacional CONyMA 2010: CD-ROM, ISBN 978-959-300-008-6. 18pp.

[9] Fernández-Vila, L.J., López-García, D. y RamírezStout, O. 2010. Características termohalinas de las aguas de la plataforma cubana. Memorias del VI Taller Internacional CONyMA 2010: CD-ROM, ISBN 978959-300-008-6. 18pp.

[10] Gómez, I., Fernández, J. L., Estrada, L. L., Olivera, Y. y Botello, A. 2014. Efecto del policultivo en el establecimiento de tres gramíneas tropicales, en un suelo Vertisol del Valle del Cauto. Pastos y Forrajes, 37(1), 24-30 pp.

[11] Lista Oficial de Plaguicidas Autorizados. Registro Central de Plaguicidas. Gaceta Oficial de la República de Cuba. 2016.

[12] Meltzoff, J. 2000. Crítica a la investigación. Psicología y campos afines.Alianza Editorial. Madrid. 195-321 pp.ISBN: 9788420686646.

[13] Montalvo, J. F. y Perigó, E. 1999. Niveles de oxígeno disuelto y materia orgánica en lagunas costeras de las regiones central y oriental de Cuba. CITMA. ISCTN. Cátedra del Medio Ambiente. Contribución a la Educación y la Protección Ambiental 0: 126-129.

[14] Montalvo, J. F., Perigó, A. E., Martínez,M., García, I., Esponda, S. C., César,M. E., García, R., López, D.,
García,N. \& Blanco, M. 2010. Compuestosde nitrógeno y fósforo en las aguas superfiiales de tres zonas de la plataforma marina cubana. Serie Oceanol., 7,27-36

[15] Norma Cubana - 25, 1999. Evaluación de los objetos hídricos de uso pesquero. Especificaciones (Oficina Nacional de Normalización, 1999a).

[16] Orta-Arrazcaeta, L. 2002. Contaminación de las aguas por plaguicidas químicos. Fitosanidad, vol. 6, núm. 3, 55-62 pp. INISAV. La Habana, Cuba. ISSN: 1562$3009 . \quad$ Disponible en: http://www.redalyc.org/articulo.oa?id=209118292006.

[17] Pis, Ma. A., Delgado, G., Hernández, D., Diéz, J., Martínez, Y., Hernández, A., Rico, O. 2014. Contaminantes químicos en agua, sedimento y camarón rosado Farfantepenaeus notialis del golfo de Guacanayabo. Revista electrónica de Veterinaria 15(2). ISSN 1695-7504.

http://www.veterinaria.org/revistas/redvet/n020214.ht mlóhttp://www.veterinaria.org/revistas/redvet/n02021 4/021407.pdf

[18] Ricardo-Mariño, C. 2009. Métodos de análisis de residuos de plaguicidas. 218, 239 pp. ISBN 978-95905-0573-7.

[19] Vázquez - Moreno, L. 2006. La lucha contra las plagas agrícolas en Cuba. De las aplicaciones de plaguicidas químicos. Por calendario al manejo agroecológico de plagas. FITOSANIDAD vol. 10, no. 3. Comunicación para la fito protección

[20] Zhang, A., Fang, L., Wang, J., Liu, W., Yuan, H.,Jantunen, L. and Li.,Yi-Fan 2012. Residues of Currently and Never Used Organochlorine Pesticides in Agricultural Soils from Zhejiang Province, China. $J$. Agric. Food Chem., 2012, 60 (12), pp 2982-2988.

Annex 1: Interviews carried out to some farming of the coastal area of study.

\section{Fishery Research Center}

Calle 246 No. 503 / $5^{\text {ta }}$ Ave y mar, Sta. Fe, Havana.

Phone.- 72097107

Related to this survey: malvarez@cip.alinet.cu

INTERVIEWS on aspects of pesticide use in the coastal area of Granma

No. Town: Province Date:

The Fishery Research Centeris carrying out a survey in the coastal area of Granma province to have preliminary information on some aspects of pesticide use in this region. This survey pursues as main objective to enlarge the level of information. We thank you for dedicating some minutes to answer these questions. Please read attentively and express free ly your criterion. 
First and Last names (optional):

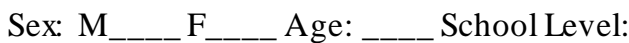

1.-Do you use pesticides or do you know any farmer that uses them?

Yes __ No __ I don't know

2.-Do you know the application doses recommended per cultivation type?

Yes ___ No

3.-Do you know of mortalities of fish or other organisms in the coastal area associated to pesticide dumping or spills? Yes __-_ No

4.- Mention any comment on the topic that you want to express. 